\title{
VAIMSE VASTUPANU PÜÜDED OKUPATSIOONIVÕIMUDELE Hugo Raudsepa 1940. Aastate KOMÖÖDIATES
}

\author{
Anu Raudsepp
}

Poetess Betti Alver sõnas omariikluse hävingu eel prohvetlikult: "Nüüd vaim on vardas ja väntab härg." 1940 . aastatel kehtestasid Natsi-Saksamaa ja Nõukogude Liidu totalitaarsed okupatsioonivõimud range tsensuuri ja suunasid ideoloogiliselt kogu eesti vaimuelu. Põhiliselt teatakse "vaimu vardasse tõmbamise" mehhanisme ja tulemusi, ${ }^{2}$ aga eestlaste vaimset vastupanu ehk leppimatust toonase valitseva ideoloogiaga on väga vähe uuritud.

Isegi vaimse vastupanu mõiste pole veel selgesti lahti kirjutatud. Vaimset vastupanu kirjanduses sõjajärgse stalinismi ajal $(1944-53)^{3}$ on käsitlenud Tiit Hennoste. ${ }^{4}$ Tema sõnul oli vaikimine "Stalini aja kirjandusliku vastupanu keskne ja praktiliselt ainus vorm". ${ }^{5}$ Vaikimine tähendas, et välditi võimule meelepäraste teoste loomist. Selle alla liigitab Hennoste ka valikulise

\footnotetext{
1 Võim ja vaim: album Eesti Üliõpilaste Selts "Veljesto" 2o-ks aastapäevaks (Tartu: EÜS “Veljesto" Kirjastus, 1940), 88.

2 Vt nt Eesti Rahva kannatuste aasta: koguteos II (Tallinn: Eesti Kirjastus, 1943); Lembit Raid, Vaevatee: Tartu Ülikool kommunistlikus parteipoliitikas aastail 1940-1952 (Tartu: Tartu Ülikooli Kirjastus, 1995); Sirje Olesk, "Neljakümnendad I: murrang kodumaal", Muutuste mehhanismid Eesti kirjanduses ja kirjandusteaduses (Tartu: Eesti Kirjandusmuuseum, 2000), 149-172; Toomas Karjahärm, Väino Sirk, Kohanemine ja vastupanu: Eesti haritlaskond 1940-1987 (Tallinn: Argo, 2007); Tiiu Kreegipuu, "Eesti kultuurielu sovetiseerimine: Nõukogude kultuuripoliitika eesmärgid ja institutsionaalne raamistik aastatel 1944-1954", Eesti NSV aastatel 1940-1953: Sovetiseerimise mehhanismid ja tagajärjed Nõukogude Liidu ja Ida-Euroopa arengute kontekstis, Eesti Ajalooarhiivi Toimetised, 15 (22) (Tartu: Eesti Ajalooarhiiv, 2007), 352-388; Tiiu Kreegipuu, The ambivalent role of Estonian press in implementation of the Soviet totalitarian project (Tartu: Tartu Ülikooli Kirjastus, 2011); Kultuur Eestis sõja-aastail 1941-1944, Tallinna Pedagoogikaülikooli Toimetised, Humaniora, A 10 (Tallinn, 1998); Riho Altnurme, Eesti Evangeeliumi Luteriusu Kirik ja Nõukogude Riik 1944-1949 (Tartu: Tartu Ülikooli Kirjastus, 2001).

3 Anu Raudsepp, Ajaloo õpetamise korraldus Eesti NSV eesti óppekeelega üldhariduskoolides 1944-1985, Dissertationes Historiae Universitatis Tartuensis, 10 (Tartu: Tartu Ülikooli Kirjastus, 2005), 11.

4 Tiit Hennoste, "Kirjandus kui vastupanu Nõukogude Eestis Teise maailmasõja järgsel perioodil”, Ajalooline Ajakiri, 2/3 (2018), 225-251 (230-231).

5 Ibid., 230.
} 
vaikimise, ehk oma rõhuasetuste valiku, ning kahestumise, ehk paralleelselt nii iseendale sahtlisse kui ka trükis avaldamiseks kirjutamise. ${ }^{6}$ Leidus aga teisigi vaimse vastupanu viise: tegelike sündmuste jäädvustamine päevikutes kaasaegsete silme läbi, vaimselt nauditava kirjanduse lugemine jms.

Siinset teemavalikut inspireeris kooliõpetaja ja tõlkija Kusta Mannermaa $(1888-1959)^{7}$ päevik aastatest $1943-59^{8}$, kus ta jäädvustas ajalugu ning arutles muuhulgas kirjandus- ja teatrielu üle. Uurimuse peamine eesmärk on selgitada vaimse vastupanu püüdeid ajaloolises kontekstis ühe 20. sajandi silmapaistvaima Eesti näitekirjaniku Hugo Raudsepa (18831952) 1940. aastate komöödiates. Näitekirjandus oli ideoloogiliselt ilmselt üks kontrollitumaid kirjanduse liike. Kuna see loodi avalikuks esitamiseks, pidid autorid olema sõnastuses eriti hoolikad. Teisest küljest andsid näidendid nii autoritele kui ka lavastajatele võimalusi peita ridade vahele varjatud sõnumeid. Seetõttu muutus Eestis teater nõukogude aja lõpukümnenditel äärmiselt populaarseks. Eriti nauditi nõukogude võimu pilamist ja naeruvääristamist. Nõukogude aja esimese kümnendi teatrielu on aga jäänud tänaseni vähe uuritud valdkonnaks.

\section{Hugo Raudsepa vaimne vastupanu esimesel nõukogude aastal 1940-41}

Teise maailmasõja ajal valitsesid Eestit kõigepealt Nõukogude Liit (1940-41) ja seejärel Saksamaa (1941-44). Ühiskond korraldati ümber ja alustati vaimuelu allutamist okupatsioonivõimude ideoloogilistele nõuetele.

Nõukogude kultuuripoliitika Eestis lähtus ÜK(b)P (alates 1952. aastast NLKP) juhtnööridest, mille põhieesmärk oli kasvatada vene keelt kõnelevaid, isikupäratuid ja riigile kuulekaid nõukogude inimesi, kes aitaksid õigustada, kindlustada ja täiustada nõukogude võimu. Sihile jõudmiseks tuli hävitada või ümber hinnata eesti varasem rahvuskultuur ja luua uus, nõukogude kultuur. Kommunistliku partei peamine kontrollimehhanism oli tsensuur, mille teostamiseks loodi 23. oktoobril 1940 ENSV Glavlit ehk Kirjandus- ja Kirjastusasjade Peavalitsus. ${ }^{9}$ Loomeinimeste tegevuse

\footnotetext{
$6 \quad$ Ibid., 230-231.

7 Vt ka Anu Raudsepp, "Kooliõpetaja Gustav Martinsoni (1888-1959) rahvuslikkultuuriliste vaadete mõjutegurid Esimeses maailmasõjas", Ajalooline Ajakiri, 1 (2018), 3-26; Anu Raudsepp, "Erakirjad infoallikana Eesti ja Lääne vahel stalinismist sulani (1946-1959)”, Ajalooline Ajakiri, 4 (2018), 255-281.

8 Anu Raudsepa erakogu.

9 Tõnu Tannberg, ““Tsensuuri töö on väga vastutusrikas.” Dokumentaalne pilguheit Eesti NSV Glavliti tegevusele aastatel 1941-1948”, Ajalooline Ajakiri, 4 (2018), 337-356 (337).
} 
süstemaatilise kontrolli ja ettekirjutuste väljatöötamiseni esimesel nõukogude aastal siiski veel ei jõutud. Paljud silmapaistvad kultuuritegelased vaikisid või teenisid leiba tõlkimisega (nt Oskar Luts, Karl August Hindrey, Hendrik Visnapuu, August Gailit, Marie Under jt). ${ }^{10}$

Tütre meenutuste järgi tuli Hugo Raudsepp esimesest nõukogude aastast otsekui ime läbi puhtalt välja. Ta olevat mänginud oma rolli uues ühiskonnas harukordse leidlikkusega, kirjutamata midagi marksistlikku ega stalinistlikku. ${ }^{11}$ Sellest ajast säilinud Hugo Raudsepa kirjatööd aitavad seda väidet kinnitada.

25. novembril 1940 retsenseeris Hugo Raudsepp esimest nõu-

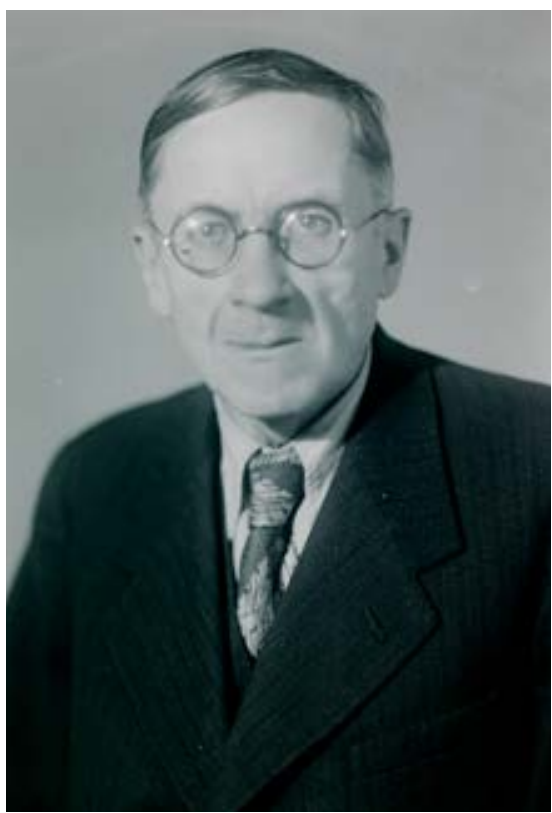

Joonis 1. Hugo Raudsepp, jaanuar 1949. RA, EFA, 242.4.5410 kogulikku näidendit "Mõõk väravas" (autor Mart Raud). Teose tegevus toimub Eesti vanglas 1940. aasta juunipöörde ajal, peategelasteks on poliitvangid. Sündmused kulmineeruvad vangide vabastamisega. Raudsepp ei hinnanud Mart Raua esimest näidendit eriti kõrgelt: "Kujude ilmetuse udususe tõttu näidendile ei saa omistada kirjanduslikku taset. Kuid teose aktuaalne aine, miljöö tabavus, teatud tehniline rakendusoskus annavad siiski näidendi, mis võib oma ajakasutusega meeleolu sünnitada ja lavalist edu saavutada. Selles mõttes käsikirja kirjastamine oleks õigustatud."12 "Mõõk väravas" ilmus trükis ja esietendus Vanemuise teatris 1941. aasta jaanuaris (lavastaja Kaarel Ird), kuid lavastus ei kujunenud menukaks. ${ }^{13}$

1940. aasta detsembri lõpuks valmis Raudsepal romaani "Viimne eurooplane” käsikiri, teos ilmus 1941. aasta mais. Romaani, mis käsitleb

\footnotetext{
10 "Kirjanikud intensiivsemalt loovale tööle", Sirp ja Vasar, 22.02.1941; Õie Elango, "Eesti kirjanikud 1940. a. sündmuste keerises", Sirp ja Vasar, 20.06.1975.

11 Hugo Raudsepa kannatustee (Stockholm: EMP, 1973), 47.

12 Eesti Kirjandusmuuseum (Edaspidi EKM) EKLA, F 16 M 293:2, 3.

13 Karin Kask, Eesti Nõukogude teater 1940-1965 (Tallinn: Eesti Raamat, 1987), 55.
} 
Eesti kultuuritegelaste vaateid ja tundeid Teise maailmasõja eelõhtul, peetakse tänapäeval Raudsepa üheks silmapaistvamaks tööks.

Raudsepp kirjutas sel perioodil ka ühe näidendi. Nimelt kuulutati 1941. aasta alguses välja ideekavandite võistlus uute lavateoste loomiseks. ${ }^{14}$ Konkursitöödest valiti välja kuus näidendit, mida peeti pärast mõningast ümbertöötamist sobivaks: Artur Adsoni "Maarahva laulik”, August Jakobsoni “Tee viib mäkke”, Albert Kivikase "Pööripäev", August Mälgu "Peale tormi" ja Hugo Raudsepa "Uutel radadel”. ${ }^{15}$ Täpsemad andmed sellest Hugo Raudsepa käsikirjast puuduvad.

Esimesel nõukogude aastal Hugo Raudsepa omariikluseaegseid näidendeid Eesti teatrites ei lavastatud. Alles 1941. aasta kevadel valmis riikliku lavakunstikooli üliõpilaste ühe eksamilavastusena Estonia teatris tema "Vedelvorst", aga etendused jäid Saksamaa ja Nõukogude Liidu vahel puhkenud sõjategevuse tõttu ära. ${ }^{16}$

\section{Hugo Raudsepa vaimne vastupanu Saksa okupatsiooni ajal 1941-44}

Natsi-Saksamaa alustas sõda Nõukogude Liidu vastu 22. juunil 1941 ning juba 7. juulil ületasid Saksa väed Nõukogude Liidu poolt annekteeritud Eesti piiri. Eesti teatritele andsid tegevuslube Saksa sõjavalitsuse (tegutses detsembrini 1941) välikomandantuurid, okupatsioonivõimu käepikendusena loodud Eesti Omavalitsuse (asutatud 15.09.1941) Politseivalitsuse prefektuurid ja Eesti Kindralkomissariaadi (05.12.1941 loodud tsiviilvalitsus) piirkonnakomissarid. ${ }^{17}$ Alates 1943 . aastast võis etendusi lubada või keelata veel teatrite majandus- ja administratiivküsimustega tegelev Tallinna teatrite intendant. ${ }^{18}$ Lavastused allutati eel- ja järelkontrollile. Keelatud olid Saksamaale sõja kuulutanud riikidest pärit ning nõukogude ja juudi autorite teosed. ${ }^{19}$ Väidetavalt kehtis Saksa ajal näitekunstile küllalt karm

\footnotetext{
$14 \quad$ Ibid., 70.

15 “6 dekaadinäidendit ümbertöötamisel”, Sirp ja Vasar, 31.05.1941.

16 Kask, Eesti Nõukogude teater 1940-1965, 49.

17 Rahvusarhiiv (edaspidi RA), ERA.R-81.3.5: Teatrite repertuaar ja etenduste aruanded, $1942-43$.

18 Agnes Toomla, "Estonia teatri ooperi- ja operetilavastused Saksa okupatsiooni ajal (1941-1944): teatri toimimine, repertuaar ja retseptsioon", Eesti Muusikateaduse Seltsi Aastaraamat, 5 (2013), 30. Pole teada, kas taolised teatrite intendandid olid ametis ka teistes linnades.

19 Saksa okupatsiooni aja teatritsensuuri kohta vt Aksel Küngas, "Sõja-aastate teatrielu üldkorraldus ja selle kaudjuhtimine”, Kultuur Eestis sõja-aastail 1941-1944 (Tallinn: Tallinna Pedagoogikaülikooli Toimetised, 1998), 76-81.
} 
tsensuur ${ }^{20}$, aga seda ei rakendatud nii järjekindlalt kui hiljem Stalini ajal. ${ }^{21}$ Saksa okupatsiooni aja teatrilugu uurinud Aksel Küngase hinnangul suudeti Eesti teatris ustavaks jääda rahvuslikule mõttelaadile ning publik sai sellest raskel ajal hingetuge. ${ }^{22}$

Väidetavalt kohandas Hugo Raudsepp Saksa okupatsiooni alguses nõukogude ajal kirjutatud näidendi "Uutel radadel" muutunud oludele vastavaks ja pani selle pealkirjaks "Sündmused agulis". Karin Kase sõnul kärpis ta sellest väikekodanlikku mentaliteeti pilavast näidendist nõukogulikku eluhoiakut jaatavaid repliike. ${ }^{23}$ Teose lavastus esietendus 1942. aasta sügisel Eesti Draamateatris ${ }^{24}$ ja Vanemuises ${ }^{25}$ ning 1943. aasta kevadel Ugalas. ${ }^{26}$ Kriitikud ei pidanud seda küll ei Hugo Raudsepa ega eesti näitekirjanduse suursaavutuseks, kuid publik võttis apoliitilise näidendi siiski hästi vastu.

Hugo Raudsepp kirjutas esimese Saksa okupatsiooni aasta järel sahtlisse oma mõtteid Eesti teatrielust, andes sellele rahuldava hinnangu. Ta märkis näitekirjanduse loomise võimaluste kohta sõjaaegse tsensuuri tingimustes: "Peame euroopalikkude nähete suhtes erapooletud ja ettevaatlikud olema, me ei tohi oma tundeid ilmutada. Meil on juba algupärandeid kinni jäänud välispoliitiliste konjunktuuride taha ning pole mõtet siin uute sarnastega riskida. Samuti pole praegu heaks tooniks ka sisemisi konflikte teravamalt kujutada, see häiriks vajalikku kodanikurahu. Millega me algpärandid veel tegeleda saaksid, need on perekondlikud motiivid. Nii asetab me sisemine seisukord ja vali erapooletus väljapoole nõudeid, mis tugevasti halvab nii näitekirjanduse kui ka teatri aktuaalsust. Peame vist jälle õppima "kaudset" kõnet, et ridade vahelt mõista anda, mida ei saa öelda. Aga kui ka olud kitsamaks ja raskemaks muutuvad, senised kogemused pole murdnud me optimismi." ${ }^{27}$ Edaspidi lähtuski Hugo Raudsepp nii Saksa kui ka sõjajärgse stalinismi ajal oma komöödiates ridade vahele kirjutamisest, et panna nii lugejaid kui teatrikülastajaid elu üle kaasa mõtlema ja anda neile hingejõudu.

\footnotetext{
20 Lauri Vahtre, “Saksa okupatsioon 1941-1944: kultuur ja olme”, Eesti ajalugu VI, peatoim Sulev Vahtre (Tartu: Ilmamaa, 2005), 210.

21 Madli Pesti, Eesti teatri 100 aastat (Tallinn: Post Factum, 2018), 64.

22 Küngas, "Sõja-aastate teatrielu üldkorraldus ja selle kaudjuhtimine", 81.

23 Kask, Eesti Nõukogude teater 1940-1965, 112.

24 Woldemar Mettus, “"Sündmused agulis” E. Draamateatris 26.9.42”, Eesti Sõna, 29.09.1942.

25 V. Austa, “"Sündmused agulis” Vanemuises”, Eesti Sõna, 20.10.1942.

26 “"'Sündmused agulis”. H. Raudsepa järjekorralise näidendi esietendus "Ugalas””, Sakala, 29.03.1943.

27 EKM EKLA, F 244 M 2:3: Hugo Raudsepp, neli kirja Peet Vallakule, artikkel 6.I 1939-10.XII 1943, dateerimata, Teater esimesel sõjatalvel, 5/5-5/7.
} 
Komöödia "Vaheliku vapustused"28, mis hiljem tituleeriti Raudsepa üheks tippeoseks ${ }^{29}$, esietendus Eesti Draamateatris 18. aprillil 1943. ${ }^{30}$ Mannermaa kirjutas 23. aprillil 1943 oma päevikus: "H. Raudsepp on kirjutanud näidendi "Vaheliku vapustused", kus kõneldakse popsi Rein Raasuke'se hädadest, mis tal tekivad sellest, et tema kaks naabrit, rikkad taluperemehed ta koha pärast kohut käivad ja et koht kord ühele, kord teisele läheb, ja vaesel Reinul jälle ümber orienteeruda tuleb. Vägisi kisub mõtlema väikese rahva saatusele kahe vägeva vahel." ${ }^{31}$ Kirjanik peitis tõepoolest ridade vahele palju vihjeid Eesti rahva saatusele. Näidendi tegevus toimub küll 20. sajandi alguses tsaariajal, aga tekst viitab hoopis Saksa okupatsiooni ajale. Eestit kujutab Vaheliku vabadik, kellel pole isegi oma kaevu (vihje omariikluse kaotamisele). Vaheliku vabadikukoht kuulub Saksamaad sümboliseerivale peremehele, vanasaks Imaanuelile, kes on usklik ja kellele meeldib heledapäine Eeva (vihje rassipoliitikale). ${ }^{32}$ Nõukogude Liitu sümboliseeriv peremees Ants irvitab jumala üle (vihje nõukogude ateismile), joob kui hobune ja möirgab kui härg (vihjed kommunistide robustsusele). Ta tahab Vaheliku vabadikku endale tagasi saada, lubades vabadikku kaitsta: "Kuldne põli tuleb sul minuga. Juua saad peatäie, peksa saad keretäie, mida sa veel tahad?" (vihjed Nõukogude okupatsioonile 1940-41). ${ }^{33}$ Vabadik muretseb Eesti saatuse pärast: "Kes ma olen? Kus ma olen? Mis must saab?"34 Tema otsus ajada edaspidi oma joont ja laulda omal viisil näitab omariikluse taastamise lootust.

Peagi näidend keelati. ${ }^{35}$ Hugo Raudsepp kommenteeris seda hiljem uue Nõukogude okupatsiooni alguses nii: “...küll vist sakslased leidsid näidendi tuumast midagi, mis neid riivas, ja "Vahelik" võeti kavast ära. Kuna see kõik sündis aga pärast kolmandat ${ }^{36}$ ettekannet, siis olid peaaegu kõik, kes seda näha soovisid, seda näinud, ja need, kes näinud ei olnud, said selle sisust teada teatrit külastanute jutustuste kaudu. Nii et "Vahelik"

28 Vt nt Eesti kirjanduse ajalugu, $V k d$, 1. rmt, toim Maie Kalda (Tallinn: Eesti Raamat 1987), 55; Kask, Eesti teater 1940-1965, 113; Cornelius Hasselblatt, Eesti kirjanduse ajalugu (Tallinn, Tartu: Tartu Ülikooli Kirjastus, 2016), 467.

29 Ants Järv, "Koomilise meisterlik valitseja” [saatesõna], Hugo Raudsepp, Vaheliku vapustused (Tallinn: Loomingu raamatukogu, 2003), 74.

30 RA, ERA.R-81.3.5: Eesti Omavalitsuse Haridusdirektoorium. Teatrite repertuaar ja etenduste aruanded, 1942-43, 67 .

31 Kusta Mannermaa päevik 1943-59, 2.

32 Raudsepp, Vaheliku vapustused, 18.

33 Ibid., 64.

$34 \quad$ Ibid., 18, 69.

35 Ants Järv, "Koomilise meisterlik valitseja", 77-79.

36 Etenduste arvud varieeruvad kirjanduses kolmest 31-ni. Vt Ants Järv, “Koomilise meisterlik valitseja", 77-79. 
läks ikkagi rahva sekka ja ta ära keelamine oli talle veel kasuks, sest kõiki huvitas repertuaarist kustutatud näidendi sisu." ${ }^{37}$

1943. aasta sügisel jätkus Raudsepa komöödiate keelustamine: 7. oktoobril keelas Tallinna teatrite intendant Paul Randpõld Raudsepa järgmise näidendi ("Teine isa") etendamise. ${ }^{38}$ Teose sisuks oli 1930. aastate lõpus toimuv armudraama. Seejärel keelati ka juba lavastatud Raudsepa näidendite edasine etendamine: "Sündmused agulis" (Vanemuises ja Ugalas, Eesti Draamateatris, Narva teatris, teatris Kannel) ja "Vedelvorst" (Tallinna Töölisteatris ja Rakvere teatris). Samuti ei lubatud lavastada tema komöödiaid "Mikumärdi" ja "Demobiliseeritud perekonnaisa". 39

Teadaolevalt jäi Raudsepa loomingust ainsana repertuaari "Lipud tormis" (Ugalas ja Eesti Draamateatris). ${ }^{40}$ Selle 1937. aastal trükis avaldatud teose ${ }^{41}$ tegevus toimub Esimese maailmasõja ajal, 1917. aasta suvest sügiseni, algul Venemaal, seejärel Eestis. Ajaloolise teemana on Hugo Raudsepa teksti lähtealuseks lisaks 1917. aasta veebruarirevolutsioonile ka Vene armees teeninud eestlaste rahvusväeosade loomine ja kodumaale saatmine, sest sakslased alustasid edukat pealetungi Eesti suunas. Näidendis ütleb esialgu Vene väes, hiljem aga Eesti polgus teeniv eesti sõjamees vene tüdrukule: "Sakslane seisab maa väravas...Sa ei tea, mida tähendab meile sakslane! Kõik eesti mehed tõttavad koju. Üle kogu Venemaa...rahvusväeossa." ${ }^{\text {"42 }}$ Lavastust kiideti venelasi ja bolševismi naeruvääristavate fraaside ja stseenide eest. ${ }^{43}$ Pole teada, kuivõrd erines lavastuse tekst näidendist.

Eesti Omavalitsuse Haridusdirektooriumi haridusasjade asedirektor Juhan Vasar (1905-72) palus 17. mail 1944 Eesti Kindralkomissariaadi kultuuripoliitika osakonnalt luba lavastada Raudsepa komöödiad "Mikumärdi", "Sündmused agulis", "Vedelvorst", "Teine isa" ja "Demobiliseeritud perekonnaisa", ${ }^{44}$ aga seda ei lubatud. ${ }^{45}$

Saksa okupatsiooni ajal oli Hugo Raudsepal loomingu keelustamise tõttu väga raske, aga ta pidas enda sõnul vastu: "Kes aga arvas, et Raudseppa nii murda saab, eksis, sest mu nimi üksi juba tingib, et minus peab

\footnotetext{
"Vestlus kirjanik Hugo Raudsepaga", Sirp ja Vasar, 24.02.1945.

RA, ERA.R-81.3.5, 1. 57p: Teatrite repertuaar ja etenduste aruanded, 1942-43.

Ibid.

Ibid.

Hugo Raudsepp, Lipud tormis (Tallinn: Eesti Kirjanikkude Liidu Kirjastus, 1937).

Ibid., 12.

“"Lipud tormis" esietendus Eesti Draamateatris Tallinnas”, Postimees, 29.04.1942.

RA, ERA.R-81.3.5, 1. 18-18p.

Ibid.
} 
olema midagi raudset. Oligi raudset visadust. Müüsin mõningaid esemeid ja elasin. Loomingulist tööd ei teinud, selleks ei olnud tahtmist.” 46

\section{Hugo Raudsepa vaimne vastupanu sõjajärgse stalinismi esimestel aastatel 1945-46}

1944. aastal lõppes Saksa okupatsioon ja algas taas Nõukogude okupatsioon (1944-91). Stalinlikku kultuuripoliitikat Eestis mõjutasid põhiliselt neli ÜK(b)P Keskkomitee otsust.

- "Ajakirjadest “Zvezda” ja "Leningrad”“ (14. august 1946);

- "Draamateatrite repertuaarist ja abinõudest selle parandamiseks" (26. august 1946);

- "Kinofilmist "Suur elu”“" (4. september 1946);

- "V. Muradeli ooperist "Suur sõprus"“ (10. veebruar 1948).

Kunstialasid (sh kirjandust) koordineeris Nõukogude Liidu Rahvakomissaride Nõukogu juures asuv Kunstide Komitee ja selle allasutusena ENSV Kunstide Valitsus (1944-53). Viimane pidi läbi vaatama ja kinnitama teatrite repertuaari, korraldama kunstinäitusi, laulupidusid, kontrollima ja koordineerima kunstialade kaudu loomingulistesse liitudesse (ENSV Heliloojate Liit, ENSV Kirjanike Liit ja ENSV Teatriühing) kuuluvate inimeste tegevust jms. ${ }^{47}$

Kirjandus allus veel ENSV Glavliti eel- ja järelkontrollile. ${ }^{48}$ Glavlit pidi jälgima, et kogu kirjasõnas hoitaks õiget ideoloogilist joont, ära hoidma sõja- ja riiklike saladuste avaldamise ajakirjanduses, puhastama raamatukogusid ja raamatukauplusi keelatud kirjandusest ning kontrollima näituseid ja maakondades teatrite repertuaari. ${ }^{49}$

Hugo Raudsepa omariiklusaegne looming jõudis Teise maailmasõja järel kummalgi pool raudset eesriiet taas teatrilavale: 1945. aastal etendus Valga teatris Säde "Põrunud aru õnnistus" ja 1946. aastal Saksamaal eesti pagulasteatris "Vedelvorst". ${ }^{50}$ Uusi näidendeid pidi kodumaale jäänud Raudsepp hakkama kirjutama samamoodi nagu kõik teised kirjanikud,

\footnotetext{
46 "Meie provintsiteatrite elust", Sirp ja Vasar, 06.01.1945.

47 Anu Raudsepp, "Kirjandus ja stalinistlik kultuuripoliitika Eestis", Muutuste mehhanismid Eesti kirjanduses ja kirjandusteaduses: ettekandeid ja artikleid 1999 (Tartu: Eesti Kirjandusmuuseum, 2000), 140-141.

48 Vt Tannberg, “Tsensuuri töö on väga vastutusrikas.” Dokumentaalne pilguheit Eesti NSV Glavliti tegevusele aastatel 1941-1948”, 337-356.

$49 \quad$ Ibid., 341.

50 “Eesti Rahvusteater Saksamaal”, Eesti Teataja, 06.07.1946.
} 
lähtudes etteantud temaatikast. ${ }^{51}$ ENSV Kirjanike Liidu 1946. aasta tööplaanidest selgub, et paljud kirjanikud kavatsesid jätkata varem alustatud või kavandatud töid või kirjutada memuaare. Sageli anti vaid lakoonilisi lubadusi. Nii lubas ka Hugo Raudsepp kirjutada ühe näidendi igal viisaastaku aastal (neljas viisaastak oli 1946-50). ${ }^{52}$ Tema söandas ühena vähestest ka Nõukogude võimu tingimusi sel ajal kritiseerida: "Kas ideoloogiast üksi piisab, et kasvatada täisväärtuslikke nõukogude inimesi? Igapäevase elu kogemused näitavad, et ei piisa. On tekkinud lüngad moraalses käitumises inimeste juures, kes pikemat aega on saanud ideoloogilist valgustust. Mul on tunne, et selle probleemi õigesse valgusesse asetamisel oleks põhjapanev tähtsus sotsialismi ülesehitamisel üldse ja viisaastaku viljakal läbiviimisel eriti." ${ }^{53}$

Aastatel 1945-46 ei kirjutanud Hugo Raudsepp veel nõutud nõukogude temaatikal, vaid otsis ainest varasemast ajast. Tema esimene nõukogulik näidend oli 1945. aastal kirjutatud "Rotid" ${ }^{54}$, mis ilmus trükis 1946. aastal. ${ }^{55}$ Näidendi tegevus toimub Saksa okupatsiooni ajal ühes Eesti linnas, tegelasteks on gümnaasiumidirektor oma perega, õpilased-õpetajad, kohalikud elanikud ja saksa sõjaväelased. Lavastus esietendus Estonias 18. jaanuaril 1946 (lavastaja Andres Särev). Kuu aega hiljem kiideti kirjaniku oskust tabada "saksa okupantidest "rottide" üht palet, võimast iha kõige söödava ja lõbustava järele". ${ }^{56}$ Sama näidendit kritiseeriti teravalt aga 16. märtsil 1946 ENSV Teatriühingu koosolekul. Kirjandusteadlase Nigol Andreseni sõnul polnud "Rotid" nõukogulik ning pääses lavale vastavate asutuste suure eksituse tõttu. Teatrimeeste ettepanekule hinnata tüki õnnestumist või ebaõnnestumist publiku seisukohast, vastas ta: "Kunst ja teater nõukogude riigis ei jookse mitte publiku sabas, vaid kõnnib ees. Kodanlikus korras hinnati tüki väärtust kassa järgi, nõukogude ühiskonnas seda olla ei saa." ${ }^{57}$

Kaks nädalat hiljem, 30. märtsil oli Nigol Andreseni hinnang näidendile "Rotid" veelgi karmim. Tema sõnul pidi nõukogude näidend andma "vaatajatele sisemist ideoloogilist sisu, mis lõpptulemusena annab nõukogude inimesele elujõudu, tööjõudu ja võitlustahet nõukogulike sihtide eest”. Andresen tunnustas küll näidendi head teemavalikut, kuid heitis

\footnotetext{
${ }_{51} \quad$ Vt Raudsepp, "Kirjandus ja stalinistlik kultuuripoliitika Eestis”, 140-143.

$52 \quad$ Ibid., 141.

53 EKM EKLA, F301, M 6:7: EN Kirjanike Liidu liikmete vastused ringkirjale 1947. a.

54 "Vestlus kirjanik Hugo Raudsepaga", 356.

55 Hugo Raudsepp, Rotid (Tallinn: RK Ilukirjandus ja Kunst, 1946).

56 Sirp ja Vasar, 16.02.1945.

57 Nigol Andresen, "Algupärandid ENSV Teatri Ühingus (Mart Raud: Karastus; Joh. Semper: Aja käsk; H. Raudsepp: Rotid)”, Sirp ja Vasar, 23.03.1946.
} 


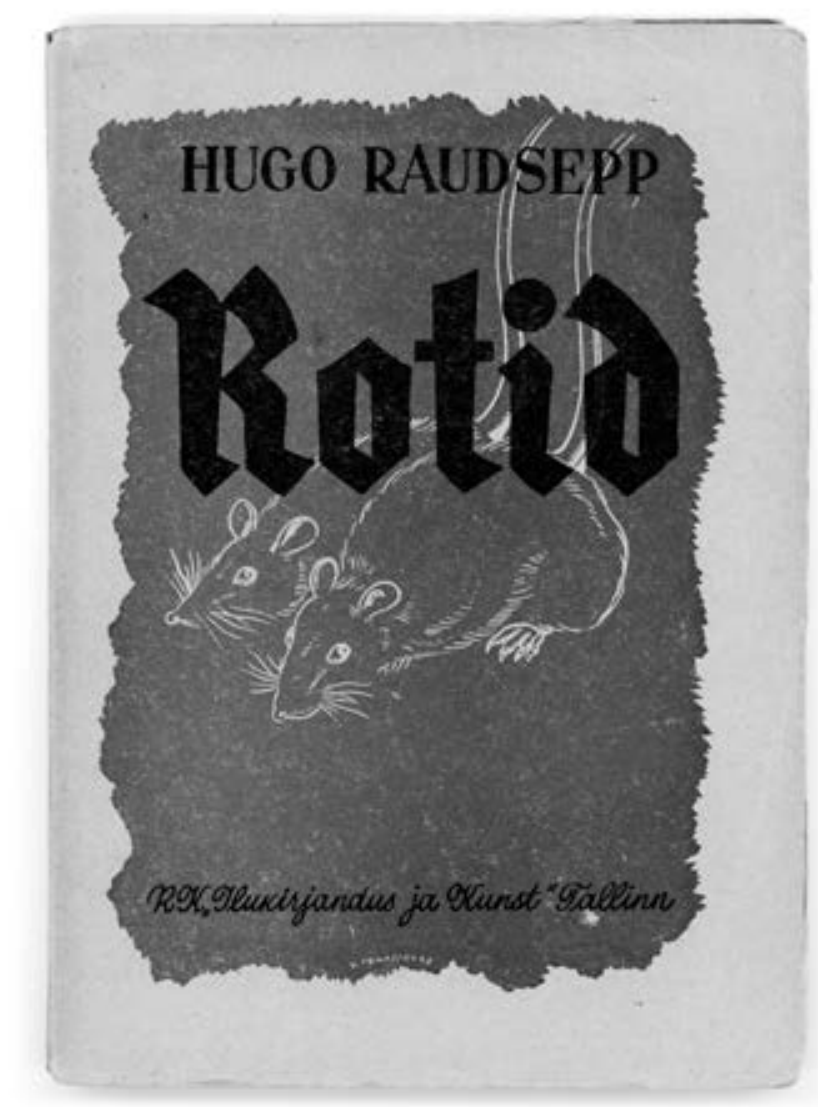

Joonis 2. "Rotid" (1946)

ette ebapiisavat viha sakslastest vaenlaste vastu - ainult tänu näitejuhile ja näitlejatele "tüüris näidend vihkamise poole". ${ }^{58}$

Näidendi "Rotid” analüüs näitab Hugo Raudsepa sõnaosavust ja oskust põimida teksti eesti kultuurilist identiteeti toetavaid sõnumeid. Näiteks võib tuua järgmise dialoogi gümnaasiumiõpilase ja tema õe vahel. ${ }^{59}$ OSKAR: (tuleb välisuksest suure hallooga): "Saa vabaks, Eesti meri, saa vabaks Eesti pind...”

VIRVE: (tuleb siseruumidest) "Mis? Mis on juhtunud?" OSKAR: "Ära tegime. See on nüüd tehtud."

$58 \quad$ Ibid.

59 Raudsepp, Rotid, 58-59. 
VIRVE: “Ära räägi!”

OSKAR: "Pärja viisime Jakobsoni sambale. Luuletusi deklameerisime nõukogude lendlehtedelt. Ja koor laulis: "Sind surmani küll tahan..."” VIRVE: "Tore! Kas sa o m a luuletuse ka ette kandsid?" OSKAR: "Kuidas siis? Põrutasin nii, et sammas värises -

See maa, kus mina sündind,

on minu kodumaa.

Ei ükski või maailmas

mind temast lahuta."

Võib ainult aimata, millist mõju avaldasid selle dialoogi sõnumid eesti inimestele. Oluline oli laulu "Saa vabaks, Eesti meri..." esitamine. Selle 1930. aastal ilmunud originaalversiooni sõnad kõlasid "Jää vabaks, Eesti meri...”, aga Saksa ja Nõukogude okupatsioonide ajal hakati seda laulma juba uute sõnadega. Näidendis mainitud "Sind surmani" oli isamaalauliku Lydia Koidula luuletus. Tekstis nimetatakse ilmselt igaks juhuks tsensuurile mõeldes ka nõukogude propagandalendlehti, mida Teise maailmasõja ajal Nõukogude lennukitelt Eestisse visati, aga mida enamasti tõsiselt ei võetud. Esmatähtis oli eestlastele märgiliste sõnumite edastamine, mitte niivõrd nende seos konkreetse ajalooperioodi ehk Saksa okupatsiooniga.

Estonias lavastatud "Rotid" jõudis küll lavale, aga siis etendus keelati. Teatrisõber Kusta Mannermaa kommenteeris seda 30. märtsil 1946 oma päevikus nii: "Hugo Raudsepp on ka seekordsed võimumehed sisse vedanud oma näidendiga "Rotid", mida mõni aeg Tallinnas etendati, siis aga äkki ära keelati, kuna leiti olevat ideoloogiliselt halb. Just nagu sakste ajal "Vaheliku vapustused"."60

1946. aastal ilmus trükis ka Hugo Raudsepa teine komöödia “Tagatipu Tiisenoosen"61, mis pärjati sama aasta mais Kunstide Valitsuse korraldatud komöödiavõistlusel preemiaga. ${ }^{62}$ Teose tegevus toimub 19. sajandi lõpul ärkamisaegses Eestis. Näidendi nimikangelane on Tagatipu talu peremehe parunilt saadud saksa tõugu hobune Tiisenoosen (vihje baltisaksa aadlisuguvõsale Tiesenhausen). Selleski tükis demonstreeriti rahvuslikku meelsust ärkamisaegse lauluga: näidendi algul kõlab "Kuldrannake" (Ado Reinvald, Aleksander Läte), mida lauldes unistab koolmeister rahva paremast tulevikust. ${ }^{63}$ 1946. aasta juunis kavatseti uuesti avaldada isegi kolm

\footnotetext{
60 Kusta Mannermaa päevik 1943-59, 206

61 Hugo Raudsepp, Tagatipu Tiisenoosen (Tallinn: RK Ilukirjandus ja Kunst, 1946).

62 "Komöödiavõistluse tulemused selgusid", Sirp ja Vasar, 18.05.1946.

63 Raudsepp, Tagatipu Tiisenoosen, 7.
} 
Hugo Raudsepa Eesti Vabariigi ajal ilmunud komöödiat: "Ameerika Kristus", "Mikumärdi" ja "Vedelvorst". Neist viimane oli juba isegi maakonnateatrite repertuaari võetud. ${ }^{64}$ Paraku sai "Vedelvorst" etenduda vaid viis korda Võru teatris Kannel ${ }^{65}$, enne kui see keelustati. Nimelt mõjutas stalinistlikku teatripoliitikat oluliselt ÜK(b)P Keskkomitee otsus 26. augustist 1946 "Draamateatrite repertuaarist ja abinõudest selle parandamiseks". ${ }^{66}$ Selle otsusega tunnistati teatrite repertuaar mitterahuldavaks, kritiseeriti nõukogude elu teemaliste näidendite puudust ning välismaiste näidendite ja ajaloolise temaatika rohkust. Rõhutati, et nõukogude inimesi kujutatakse primitiivsetena, seevastu n-ö negatiivseid kangelasi eredamate iseloomujoontega. Otsuses nõuti nõukogude ühiskonda kujutavate teoste loomist.

ÜK(b)P Keskkomitee otsusele järgnes üleüldine puuduste otsimine senises loomingus, millest ei pääsenud ka Hugo Raudsepa näidend "Tagatipu Tiisenoosen", mis esietendus Ugalas 20. septembril 1947 (lavastaja Karl Ader ${ }^{67}$ ja Estonias 29. septembril 1947 (Ants Lauter). Esimene arvustus oli veel leebe ${ }^{68}$, aga 16. novembril 1946 toimunud Teatriühingu arutluskoosolekul nimetati näidendit ja Estonia lavastust juba ebaõnnestunuks ning soovitati kirjanikul ja lavastajal Ants Lauteril kontakteeruda ideoloogiliselt kogenenumate seltsimeestega.$^{69}$ Näidend jäi siiski lavale, esietendudes 3. jaanuaril 1947 Vanemuises (lavastaja Kaarel Ird) ${ }^{70} 23$. märtsil Valga teatris Säde (Ott Raudheiding), 13. aprillil 1947 Kuressaare teatris (Paul Kalde) ja 6. oktoobril 1949 Ugalas (Karl Ader). ${ }^{71}$

On tähelepanuväärne, et näidend "Tagatipu Tiisenoosen" jõudis 1947. aasta suvel ka Välis-Eestisse. Kirjandusloolane ja kriitik Mall Jürma kirjutas Saksamaal: "Kuna eesti kirjanikuna käesoleval ajal on teatavasti raske täita "sotsialistlikku tellimust", siis Raudsepp on küllaltki läbipaistvalt valinud teema, mis kannatab isegi "sotsialistlikku mõõdupuud". Ta kiitis Raudseppa tõusikluse pilamise eest. ${ }^{72}$ Teatritegelane Voldemar Mettus

\footnotetext{
64 "Hugo Raudsepa komöödiad uues väljaandes", Sirp ja Vasar, 22.06.1946.

65 "Teatrikunst ja dramaturgia uute edusammude eest", Sirp ja Vasar, 25.08.1951.

66 Vt "Draamateatrite repertuaarist ja selle parandamise abinõudest", Sirp ja Vasar, 07.09.1946.

67 Hugo Raudsepp: bibliograafia, koost Tiina Ritson (Tallinn: Eesti Rahvusraamatukogu, 2007), 133.

68 Rasmus Kangro-Pool, "Tagatipu Tiisenoosen "Estonia” teatris", Sirp ja Vasar, 12.10.1946.

69 “"Tagatipu Tiisenoosen” ENSV teatriühingu arutluskoosolekul”, Sirp ja Vasar, 16.11.1946.

70 Teodor Krigul, “Tiisenoosen RT "Vanemuises”“, Sirp ja Vasar, o8.02.1947.

71 Hugo Raudsepp: bibliograafia, 133-134

72 Mall Jürma,"Tagatipu Tiisenoosen: Hugo Raudsepa komöödia", Eesti Post, 01.07.1947.
} 
analüüsis “Tagatipu Tiisenoosenit” Rootsis. Tema sõnul polnud näidendis "midagi dialektilisest materialismist ega teistest leninlikest või stalinlikest "ismidest", selles "ei ennustata prohvetlikult kommunistlikku "sotsialismi" tulekut ega lasta aimata Stalini päikese eelset koitugi". ${ }^{73}$

\section{Hugo Raudsepa vaimne vastupanu 1947-51}

1947. aastast muutus ankeet, mille kirjanikud pidid igal aastal täitma, oma loominguliste nõuete poolest täpsemaks. Järgmistel aastatel tuli lisaks plaanidele ringkirju uute kohustustega. ${ }^{74}$ Nii kirjutaski Raudsepp järgmised näidendid juba nõutud nõukogulikel teemadel, alustades maareformist. Enne, kui Eestis hakati kolhoose looma, viidi 1947. aasta suvel lõpule maareform, millega anti suuremate talude arvel maad väiketaludele ja maatameestele. Maareformi lõpuks moodustasid endistest suurtest talumajapidamistest $1 / 3$ uusmaa- ja juurdelõikesaajate talud, 1/3 maareformiga vähendatud talud ja 1/3 reformist puutumata jäänud majapidamised. Maareformi tagajärjel halvenesid maal sotsiaalsed ja majanduslikud olud ning inimestevahelised suhted. Maa võõrandamisega nõrgendati sageli seni heal järjel olnud talusid, samas ei kujunenud ka uusmaasaajate majapidamised elujõulisteks. ${ }^{75}$

Nõukogude maareformist jutustav näidend "Tillereinu peremehed" valmis 1947. aasta sügisel ${ }^{76}$ ja ilmus trükis 1948 . aastal. ${ }^{77}$ Näidend jutustab Tõnis Kuhelikust, vabadikust, kes tahtis saada Tillereinu talust maad. “Tillereinu peremeeste" esietendused toimusid 18. detsembril 1947 Valga teatris Säde (lavastaja Väino Suri), ${ }^{78}$ 1948. aasta märtsis Rakvere teatris (Aleksander Viilmaa) ${ }^{79}$ ja 7. mail Estonias (Alfred Mering) ${ }^{80}$ Kui Rakvere lavastust tunnustati ${ }^{81}$, siis Tallinna omaga kriitikud rahule ei jäänud. Nimelt

\footnotetext{
73 Voldemar Mettus, "Mõisatäkk ja peremees”, Stockholms-Tidingen Eestlastele, 02.11.1947.

74 Vt Raudsepp, “Kirjandus ja stalinistlik kultuuripoliitika Eestis”, 141-142.

75 Tõnu Tannberg, "Hilisstanilistlik Eesti NSV", Eesti ajalugu VI, peatoim Sulev Vahtre (Tartu: Ilmamaa, 2005), 282-283.

76 "Tervitame Suure Oktoobri päeva uute teostega", Sirp ja Vasar, o6.11.1947.

77 Hugo Raudsepp, Tillereinu peremehed (Tallinn: RK “Ilukirjandus ja Kunst”, 1948).

78 "Tillereinu peremehed" teatris Säde, http://www.lavakas.ee/tmm/?valik=lavabaas \&id=9934\&page $=1 \&$ s_nimi $=1947$ (13.02.2020).

79 Valdeko Ratassepp, "Muljeid Rakvere teatri "Tillereinu peremeeste etenduselt", Sirp ja Vasar, 17.04.1948.

80 "Tillereinu peremehed" Estonia teatris, http://www.lavakas.ee/tmm/?valik=lavab aas\&id $=12738 \&$ page $=1 \&$ s_nimi $=1948$ (13.02.2020).

81 Ratassepp, "Muljeid Rakvere teateri "Tillereinu peremeeste etenduselt”“.
} 
olid n-ö positiivsed tegelased "abitud ja saamatud" (sulased ja popsid) ja "hallilt joonistatud" (täitevkomitee esimees). ${ }^{82}$

Rahvale meeldis aga "Tillereinu peremehed" väga ja 1948. aasta juunis oli see üks vaadatumaid lavastusi Eestis. ${ }^{83}$ Kusta Mannermaa külastas 29. augustil 1948 Tartus Estonia külalisetendust, märkides selle kohta õepojale Väino Veemehele Inglismaale saadetud kirjas, ${ }^{84}$ et selles maareformi moonutusi käsitlevas näidendis on palju koomikat. ${ }^{85}$ Teoses leidub tõepoolest palju mahlakat koomikat, mis avaldus ka tegelaste nimedes: taluperemehed Villem Võsa ja Peeter Põmakas ning ajakirjanik Meeri Nipsakas. Tõsi, viimase uueks nimeks sai lavastustes peagi Mari Pihelgas. ${ }^{86}$ Allpool on katkend vestlusest täitevkomitee esimehe (Lepikson) ja vabadiku (Tõnis) vahel, kui viimane maakrundi küsimuses valla kantseleisse kutsutakse. ${ }^{87}$ LEPIKSON: "Ja kui tuled, ära siis ka punast nurka unusta. Maad tahate saada, aga kui hakkad ideoloogiat küsima...Oled sa Marxist ja Engelsist midagi kuulnud?"

TÕNIS: "Või mitte! Päris oma silmaga olen neid mehi näind."

LEPIKSON: "K e d a sa oled näinud?"

TÕNIS: "Marxi ja ka Engelsit."

LEPIKSON: "Kus sa neid nägid? Unes?"

TÕNIS: "Pildid olid lehes"

LEPIKSON: "Pildid lehes, ahahaa!"

Rahvas sai naerda, aga võimul polnud otseselt millestki kinni hakata. Naer pakkus inimestele raskel ajal hingekosutust.

Hugo Raudsepp jagas näidendis ka õpetussõnu, kuidas võõrvõimu all ellu jääda. Ühe näitena võib tuua stseeni taluperemeeste vestlusest, milles Tillereinu peremees Villem Võsa on häiritud tema talu maadele asuniku määramisest. Peeter Põmakas esindab oma nime vääriliselt jõuga vastu hakkamise taktikat: "Kus aga saab...sõrad vastu. Tulevad tahtma, ei anna. Võtavad vägisi, tõstan kisa. Norme ei vii, plaane ei täida. Ja kui mõni agitaator mulle seletama tuleb, sõiman näo täis. Kuradi kulak, ütlevad, see pole

$82 \quad$ Arnold Tulik, "Parandatud, kuid viimistlemata lavastus. H. Raudsepa komöödia “Tillereinu peremehed” RT Estonias”, Sirp ja Vasar, 22.05.1948.

83 Bernhard Tinnuri, "Rakvere teatrist", Sirp ja Vasar, 12.06.1948.

84 Stalinismiaegse kirjavahetuse kohta vt Raudsepp, "Erakirjad infoallikana Eesti ja Lääne vahel stalinismist sulani (1946-1959)”, 255-282.

85 Kusta Mannermaa kiri Väino Veemehele 30.08.1948. Anu Raudsepa erakogu.

86 Ratassepp, "Muljeid Rakvere teateri "Tillereinu peremeeste etenduselt"”.

87 Raudsepp, Tillereinu peremehed, 14. 
inimene! Kuidas ma tohin inimene olla, kui see pole plaanis ette nähtud? Sina, Tillereinu, peaksid ka rohkem mees olema ja oma hambaid näitama."

Villem Võsa eelistab kavalust ja kannatlikkust: "Mina kära ei tõsta. Mina katsun tasa ja targu. Kui jõuga ei saa, saan nõuga. Tormistel aegadel pole tark pealisputke kasvatada, murravad maha. Nüüd on soodsam pealsetega madal olla, aga oma juurika lased hästi sügavale mulda. Avalikus võitluses jääme alla. Aga kui sulame ja sisse imbume... Sisse imbudes oleme suur jõud. Nende mure on pinnast sotsialismi jaoks ette valmistada. Kaevavad kraave, lasevad põhjavett, külvavad seemet. Aga meie seal mullakihi peidus nahistame ja roisutame. Kraavid langevad sisse, seeme määndub, umbrohi lööb vohama. Sinu roika kaksavad nad käest, aga kui nähtamatuks sisse imbume..." 88

Hugo Raudsepp tõi oma näidendisse sisse ka rahva seas üldtuntud pahe: nõukogude ametimeeste alkoholilembuse. Nii võtab näidendi täitevkomitee esimees taluperemehelt altkäemaksuna vastu Prantsuse konjaki. Ajastule ebatüüpiliselt, aga ideoloogiliselt korrektselt, tagandatakse täitevkomitee esimees oma ametist. Uus esimees, vigastuse tõttu teenistusest vabastatud ja kodukülla naasnud madrus Elmar, lööb korra majja ning Tõnis Kuhelik saab uusmaasaajana endale osa Tillereinu talust.

Järgmise päevakajalise teemana käsitles Hugo Raudsepp 1947. aasta rahareformi. Nii nagu paljud Euroopa riigid, ohjeldas ka Nõukogude Liit sõjajärgset inflatsiooni rahareformiga. See viidi läbi 16.-22. detsembril, kaugpiirkondades kestis see 29. detsembrini. Sularaha vahetati kursiga $10: 1$. Hoiused vahetati järgmiselt: summad kuni 3000 rubla $1: 1$, summad kuni 10 ooo rubla $3: 2$ (esimesed 3000 nominaalselt) ja üle 10 ooo hoiused $2: 1$. Kooperatiivsete ettevõtete ja kolhooside arvel olnud raha vahetati kursiga $5: 4$. Reform oli riigi seisukohalt edukas: liigne raha korjati käibelt, likvideeriti suured hoiused, alandati riigivõlga. Rahva elatustase langes aga märgatavalt. Reformiga kaasnenud kaupade kaardisüsteemi (kehtis aastatel 1944-47 toidu- ja tööstuskaupadele) kaotamisega ei suutnud riik tagada rahva varustamist toiduga ja lakke tõusnud turuhinnad polnud enamikule jõukohased..$^{89}$

Rahareformi teemal kirjutas Hugo Raudsepp 1948. aastal lühinäidendi "Noorsulane Ilmar". ${ }^{90}$ Näidendi sisu keerleb Tedrevälja talu peremehe Juhan Mätliku 80 ooo rubla ja talu tuleviku ümber, raha väärtuse kaotus

\footnotetext{
$88 \quad$ Ibid., 34-35.

89 Monika Levkin, “1947. aasta rahareformist NSV Liidus ja Eesti NSV-s: teostamine ja vastukajad ühiskonnas”, Oppetatud Eesti Seltsi Aastaraamat (2015), 99-119.

90 EKM EKLA F 212 M 20:4: Raudsepp, Hugo. Noorsulane Ilmar. Näidend ühes vaatuses.
} 
muserdab taluperemeest. Näidendis tuleb ilmekalt esile üks Eesti talude tõsine sõjajärgne probleem, noorte meeste puudus. Nii nagu paljudes peredes, on ka Tedrevälja talu peremehe poeg Mihkel okupatsiooniaegsete pattude pärast vangis. Koduväiks loodetud sulane Ilmar otsustab kohalike kommunistlike noorte veenmisel taluteenimise asemel hoopis loodava kolhoosi kasuks. Lõpuks peab vana taluperemees sellega leppima, kuigi see on talle väga raske. Seda väljendavad Juhani dramaatilised sõnad "Mis see siis on? Mis minu ümber sünnib? Poeg võeti käest, talu nuditi ära, raha kaotab väärtuse." Juhan tõstab rusikas käed lae poole ja ütleb: “Näed sa, mis siin minuga tehakse? Sa suur jumal taevas... või oled sa püsti kurat!"91

1949. aastal muutusid poliitilised olud nii Eestis kui ka kogu Nõukogude Liidus veelgi keerulisemaks ja hoogustus vaenlaste otsimine. Riigi teatrielus leidis aset vaenlaste paljastamise kampaania, mille korraldamisele andis tõuke ajalehes Pravda 28. jaanuaril 1949 ilmunud kriitiline artikkel "Ühest antipatriootlikust teatrikriitikute rühmast". ${ }^{92}$ Selle kirjutisega tähtsustati senisest enam stalinistlike institutsioonide poolt tehtavat kriitikat ja inimeste enesekriitikat, eesmärgiga suunata ja kontrollida võimu ideoloogiliste nõuete täitmist. See tipnes 25. märtsil 1949 küüditamisega, mille käigus saadeti sunniviisiliselt Siberisse üle 20 ooo inimese.

Kirjanikud pidid leiva teenimiseks propageerima oma loomingus ka kolhooside rajamist. 1949. aasta sügisel ilmus Raudsepalt kaks väga ettevaatlikult kirjutatud kolhoositeemalist lühinäidendit. Oma tavapärasest vaimukusest ta siiski ei loobunud. Näiteks küsib näidendis "Küpsuseksam" üks tegelane (kiuslikult): "Ja mida me tõttame? Kas me nüüd päev varem või hiljem sinna kommunismi sisse jõuame, mis sellest siis katki oleks?" ${ }^{93}$ Ühevaatuselise näidendi "Lasteaed" lõpus öeldakse pilavalt, et tänapäeval enam vanasõna "rahu kosutab, vaen kaotab" ei sobi, sest "vaid töö kosutab, võitlus karastab" ${ }^{94}$ Tagasihoidlikust sõnastusest hoolimata taipasid kriitikud nüüdki, et lavastamisel mõjuvad Raudsepa negatiivsed tegelased palju elulisemalt ja meeldejäävamalt kui n-ö positiivsed kangelased. ${ }^{95}$ Võib arvata, et see oli taotluslik.

1949. aasta sügisel kirjutas Raudsepp veel ühe komöödia. Selle tegevus toimub 1940. aasta sügisel pärast Eesti annekteerimist Nõukogude Liidu

\footnotetext{
$91 \quad$ Ibid., 23.

92 Vt "Ühest antipatriootlikust teatrikriitikute rühmast", Sirp ja Vasar, 05.02.1949.

93 Hugo Raudsepp, Küpsuseksam (Tallinn: RK Kirjastus "Ilukirjandus ja Kunst”, 1949), 31.

94 Hugo Raudsepp, Lasteaed, Isetegevus-näitelava, Stalinliku Nooruse kaasaanne, 1949, $\mathrm{nr} 12,10$.

95 Jaan Toomla, "Kahest kolhoosinäidendist", Sirp ja Vasar, 26.11.1949.
} 
poolt. Näidendi armudraamal põhineva tegevuse ja tegelaskujud võttis ta oma Saksa ajal keelatud näidendist "Teine isa" (1943), ajakohastades need uutele oludele: kui 1943. aasta loos sõideti end kultuuriliselt harima Euroopasse, siis nüüd mindi ideoloogiliselt täiendama Moskvasse jne. Alguses kandis teos pealkirja "Kauge külaline"96 (ka "Kaugelt külaline")97, seejärel "Pööripäevad Kikerpillis". ${ }^{8}$ Samuti muutis ta teksti leebemaks. Näiteks ütles kooliõpetaja esimeses versioonis: "Ajalootunnid võetavat mul käest, selle aine peale toodavat päris värske jõud", aga teises: "Lisatunnid ajaloos võetakse minult ära." Komöödiale omast nalja saab seekord näidendis vähe, kõlama jääb murelik toon: "Valitseb suur ebakindlus homse ees. Iga sammu kardad astuda." ${ }^{99}$ Näidendit püüti lavastada Vanemuises, kuid see keelati ära. ${ }^{100}$

Kultuuritegelastel oli süveneva tsensuuri tingimustes järjest raskem kirjutada. Kusta Mannermaa kirjutas 28. novembril 1949: "Kõige raskem on peaaegu haritlaskonnal, eriti neil, kes peavad kirjutama. Kirjutused lähevad küll läbi mitmest instantsist, n.ö. tsensuurist, seal aga tuleb äkki mõni parteilane ja leiab, et töö ei ole marksistlikult seisukohalt õige. Ja seepärast eriti vanemad kirjanikud, näit. Tuglas, Metsanurk, Luts ja Vallak, ${ }^{101}$ ei kirjutagi midagi. Samuti pole kerge kirjutada midagi kirjandusteadlastel ja ajaloolastel ja see põld on kaunis söötis."102

Sõjajärgne kultuuripoliitika päädis EK(b)P Keskkomitee VIII pleenumiga 21.-26. märtsil 1950, kus süüdistati EK(b)P Keskkomitee bürood muu hulgas Lääne-Euroopa teaduse ja kultuuri üleoleku ülistamise lubamises. ${ }^{103}$ Kultuuritegelasi tembeldati kodanlikeks natsionalistideks ning ees seisid uued suured katsumused. Kusta Mannermaa kirjutas 10. mail 1950 päevikus: "Haritlaste hulgas on paljud, kes saksa ajal ametis olid või midagi kirjutasid, näit. kirjanikud H. Raudsepp ja Metsanurk ${ }^{104}$ Saksa käsilasteks kuulutatud, mõnda näit. Paide teatri direktorit Opsolat ${ }^{105}$ nimetatakse isegi

\footnotetext{
96 "Kirjanike panus suurde ülesehitustöösse", Sirp ja Vasar, 15.10.1949.

EKM EKLA, F2O2 M1:15: H. Raudsepp, Kaugelt külaline.

EKM EKLA, F142, M233:3: H. Raudsepp, Pööripäevad Kikerpillis.

Ibid.

“Teatrikunsti ja dramaturgia uute edusammude eest", Sirp ja Vasar, 25.08.1951.

Friedebert Tuglas, Mait Metsanurk, Oskar Luts, Peet Vallak.

Kusta Mannermaa päevik 1943-59, 272.

103 Vt “EK(b)P Keskkomitee VIII pleenumi stenogramm”, Akadeemia, 12 (1998), 2655-2686; 1 (1999), 191-222.

104 Mait Metsanurk (1879-1957).

105 Raivo Opsola (1900-1960) arreteeriti aastal 1950 ja saadeti kuni 1954. aastani Molotovi oblastisse.
} 
neofašistiks. Kallale tungitakse isegi parteilisele teatridirektor Lauterile. ${ }^{106}$ Ei ole eesti haritlaskonnal varem nii raskeid päevi olnud."107 1950. aastal arreteeriti teatrikriitikud Rasmus Kangro-Pool ja Karin Kask. ${ }^{108}$ Ka Hugo Raudsepp tituleeriti "fašistide käsilaseks", ${ }^{109}$ ta heideti välja Kirjanike Liidust ja jäeti ilma personaalpensionist.

24. mail 1950 lõpetas Hugo Raudsepp kolhoositeemalise näidendi "Mineviku köidikuis". Tema omakäelisele pealkirjale on kellegi teise käekirjaga sulgudesse juurde lisatud "Omad witsad". ${ }^{110}$ Tõenäoliselt võis komöödiale uue nime anda tsensor. Kuna $w$-võõrtähe kasutamine kadus Eestis üldjuhul 1930. aastatel, viitab see kiri tsensori võimalikule Venemaa eestlase taustale. Tänapäeval on allikakriitilise eksimuse tõttu kasutusel tsensori (?) pandud pealkiri "Omad vitsad". ${ }^{11}$ Kirjaniku abikaasa Lydia Raudsepa väitel tõlgiti "Mineviku köidikuis" vene keelde, kuid seda ei jõutud Moskvas avaldada. ${ }^{112}$ Rahvale soovitati näidendis kolhoosi öövahi suu läbi jõuallikana Piiblit: “...nagu ka minu vanaisa vanas puukaantega piiblis on öeldud, et jumala rahu, mis ülem on kui inimeste mõistus...”113

Hugo Raudsepp märkis viimaseks jäänud näidendi käsikirjale "Viimane näidend. 1950-1951". ${ }^{114}$ Seda on seni ekslikult peetud näidendi "Mineviku köidikuis" koopiaks, pealkiri figureerib muuhulgas isegi Eesti Kirjandusmuuseumis oleva käsikirja toimikul. ${ }^{115}$ Sarnased on siiski vaid näidendite esimesed fraasid "Ruumikas tuba kolhoosi esimehe Peeter Kõvatooma kodus" 116 ja "Söögitoalise sisustusega eestuba Vapruse kolhoosi esimehe Kalmuse kodus". ${ }^{17}$ Komöödiate sisu on aga täiesti erinev. "Mineviku köidikuis" kõneleb kolhoosi karjakasvatusest, "Viimane näidend" väikekolhooside liitmisest ja kolhoosikeskuste väljaehitamisest.

Hugo Raudsepa sulg jäi lõpuni vahedaks. Ka "Viimases näidendis" leidub ridamisi Nõukogude võimu peenelt narrivaid sõnavõtte. Näidendi peategelased olid eesrindlike kolhooside juhid: Vapruse kolhoosi esimees

\footnotetext{
106 Draamateatri peanäitejuht Ants Lauter (1894-1973).

107 Kusta Mannermaa päevik 1943-59, 279.

108 Vt Mart Orav, “"See ei või olla ilmsi...” Hugo Raudsepa viimasest eluaastast”, Akadeemia, 4 (2014), 651-664.

109 "Otsustava võitluse kaudu uuele tõusule”, Sirp ja Vasar, 06.05.1950.

110 EKM EKLA, F2O2 M 11:1: Mineviku köidikuis (Omad vitsad), 1.

111 Hugo Raudsepp: bibliograafia, 20; Lydia Raudsepp, "Ärge nukrutsege minu pärast: kolmkümmend aastat ühist teed”, Akadeemia, 11 (2013), 2038-2061 (2059).

112 Raudsepp, “Ärge nukrutsege minu pärast: kolmkümmend aastat ühist teed”, 2059.

113 EKM EKLA, F 202 M 11:1, 27.

114 EKM EKLA, F 202 M 2:6: [Mineviku köidikuis(?)].

115 Ibid.

116 EKM EKLA, F 202 M 11:1.

117 EKM EKLA, F 202 M 2:6.
} 
Johannes Kalmus kolhoosi uue sõiduauto Pobedaga ja Võidu kolhoosi venelannast esinaine Anna Soobik. Tolleaegse ühiskonna n-ö antikangelast kujutab näidendis mahajäänud Kungla kolhoos, kus muuhulgas unistati oma hümnist "Kungla rahvas". Võidu kolhoosi esinaine oli lahkesti nõus sellele eestipärasele kolhoosile abikäe ulatama, et teda järele aidata. Seda saab tõlgendada Vene abina Eesti sovetiseerimisel. Kuna nii Vene kui ka Eesti kolhooside viletsus ja vaesus olid üldteada, mõjusid Venemaalt tulnud agronoom Suislepa sõnad tegelikkuse paroodiana: "No teate, mis mina selle aasta jooksul kõik näinud ja õppinud olen? Ja kuidas ma tagasi koju pöördudes nüüd ideedest otse lõhkemas olen. Ja kuidas kõik meie tuleviku perspektiivid aiva mu silme ees virvendavad. Ma lihtsalt ei saa paigal seista. Välja värske õhu kätte! Nurmedele, niitudele, soode ja võsade kallale. Elame ju suurtel stalinlikel looduse ümberkujundamise päevadel." Hugo Raudsepa viimaseks jäänud "Viimases näidendis" on tegemist nõukogude korra paroodia ja väljanaermisega. Tõenäoliselt oligi see sahtlisse kirjutatud - aeg oli ärev ja kõikjal jätkusid repressioonid.

Eesti näitekirjanduse suurkuju saatus oli väga karm. Hugo Raudsepp arreteeriti 11. mail 1951. Talle esitatud süüdistustes rõhutati nõukogudevastasust, mille põhitõenditena nimetati Saksa okupatsioonivõimu poolt keelatud näidendit "Vaheliku vapustused" ja ainsana lubatud teost "Lipud tormis". Hugo Raudsepale mõisteti 1951. aasta sügisel 10 aastat vangistust. ${ }^{118} \mathrm{Ta}$ lootis viimse hetkeni, et ta saab jääda karistust kandma Eestisse. ${ }^{119}$ Paraku saadeti ta 18. veebruaril Tallinnast rongiga Narva ja 19. veebruaril Leningradi. Sealt viis ta tee Kirovisse ja lõpuks Irkutski oblastisse. ${ }^{120}$ Kehva tervisega suurmees suri juba 15. septembril 1952.

\section{Kokkuvõte}

1940. aastatel ilmus Eestis väga vähe uusi kirjandusteoseid, sõjajärgse stalinismi aja raamatutoodangus nähakse lausa ajaloolist madalseisu. ${ }^{121} \mathrm{Ka}$ Eesti teater oli tsensuuri, repertuaaripuuduse, rahanappuse ning teatritegelaste koondamiste ja vallandamiste tõttu väga raskes olukorras. Tänapäeval hinnatakse Eesti teatri püsimajäämist sel ajajärgul, vaatamata rasketele

\footnotetext{
118 Vt Mart Orav, “See ei või olla ilmsi...", 651-664; Hugo Raudsepa kannatustee.

119 EKM EKLA, F 202 M 9:7: Hugo Raudsepp, kolmkümmend kaheksa kirja Lydia Raudsepale 23. VI 1924-19.VII 1952 ja d-ta, 33/45, 34/46: Hugo Raudsepa kiri kodustele Tallinnast 08.02.1952 ja Leningradist 19.02.1952.

120 Ibid., 34/46-36/50.

121 Hasselblatt, Eesti kirjanduse ajalugu, 474.
} 
oludele, ning tunnustatakse näitlejaid eesti identiteedi säilitamise ja rahvuse ühendamise eest. ${ }^{122}$

Hugo Raudsepa okupatsiooniaastate komöödiate põhjal tuleb tunnustada tema kui näitekirjaniku rolli vaimse vastupanu osutamisel võõrvõimudele. Hugo Raudsepp oli üks viljakamaid autoreid, kirjutades aastatel 1943-51 kokku 11 näidendit. Kirjandusteadlaste hinnangul ei tõusnud ta aga nende töödega kordagi eelneva loomingu tipptasemeni. ${ }^{123}$ Sellel rangete ideoloogiliste ettekirjutuste ja nende täitmise kontrolli ajal polnudki võimalik luua klassikasse jäävaid tippteoseid. Kirjanik mõistis seda isegi, nentides ühes sahtlisse jäänud kirjatöös irooniliselt: "Heroilistel ajajärkudel komöödia seisukord on täbar. Häid nõukogude patrioote naeruvääristada ei kõlba. Vaenlast naeruvääristada pole ka tark. Sest võideldes naeruväärse vaenlasega, mis sangarid me veel oleme!"124

Äärmiselt piiratud loomingulisi tingimusi arvestades olid tema tööd ikkagi oma aja tippteosed. Hugo Raudsepa loomingu näitel suutis eestimeelne vaim hoolimata tsensuurist ja ettekirjutustest ikkagi võimu vaimukalt üle trumbata. Ainsa stalinismiaegse näidendina lavastasid eesti pagulased Hugo Raudsepa näidendi “Tagatipu Tiisenoosen” pealkirjaga "Oheliku orjaveri" 1952. aasta märtsis Kanadas (lavastaja Kaarel Söödor), 1954 Austraalias (Jaan Mürk) ja 1956 Rootsis (Valentin Lind). ${ }^{125}$

Stalini isikukulutuse hukkamõistmine 1956. aastal avas taas võimaluse lavastada Hugo Raudsepa parimaid, omariiklusaegseid komöödiaid. 1957. aastal lavastati "Vedelvorst" (Ugala, lavastaja Aleks Sats), "Põrunud aru õnnistus" (Draamateater, Ants Särev) ja "Mikumärdi" (Vanemuine, Kaarel Ird). ${ }^{126}$ Kusta Mannermaa kirjutas 3. oktoobril 1957: "Käisin üle tüki aja jälle teatris. Tahtsin vaadata Raudsepa "Mikumärdit", mida nägin vist umbes 30 aastat tagasi. Raudseppa ei ole meil mängitud aastat viisteist, nüüd on see tulnud jälle etendusele. Kindlasti on "Mikumärdi" kõige parem ja lavalisem R. näidenditest. Vähemalt naerda saab tublisti. Ja see on ka hea asi." Hugo Raudsepa komöödiate nali ja naer andsid inimestele uut hingamist.

\footnotetext{
122 Karjahärm, Sirk, Kohanemine ja vastupanu: Eesti haritlaskond 1940-1987, 730-734. 123 Eesti kirjanduse ajalugu, $V \mathrm{kd}$, 1. rmt, 75.

124 EKM EKLA, F 202, M 9:8: Hugo Raudsepp "Humoristi mõlgutusi tänapäeva komöödiast”.

125 Hugo Raudsepp: bibliograafia, 136.

126 Ülo Tonts, Kolmkümmend aastat teatriehitamist. “Vanemuise” sõnateatrist 1955-1986 (Tartu, Teater Vanemune, 2006), 73-74.
} 


\section{Aвstract: Attempts at putting up intellectual and spiritual resistance to the occupying authorities in Hugo Raudsepp's comedies from the 1940 s}

In the 1940s, the totalitarian occupying regimes of Nazi Germany and the Soviet Union implemented the strictest control and ideological guidance of intellectual and spiritual life of all time in Estonia. Essentially, the mechanisms and results of control are known. Cultural life was subjected to strict pre-censorship and post-publication censorship, and in the Soviet era also to thematic dictation.

The intellectual and spiritual resistance of Estonians in those years, in other words their refusal to accept the ruling ideology, has been studied very little. The most widespread way of putting up intellectual and spiritual resistance was to remain silent, in other words to avoid creating works that were agreeable to the authorities. Selective silence, that is the selection of one's points of emphasis, and splitting, in other words writing for oneself works that one keeps in one's drawer while at the same time writing for publication in print, are also placed in this category. Recording actual history in diaries through the eyes of contemporaries of events, reading intellectually and spiritually enjoyable literature, and other such actions were ways of putting up intellectual and spiritual resistance.

The main objective of this study is to ascertain in historical context the attempts to put up intellectual and spiritual resistance in the comedies from the 1940s by Hugo Raudsepp (1883-1952), one of the most outstanding Estonian playwrights of the $2 \mathrm{O}^{\text {th }}$ century. Ideologically speaking, dramatic literature was clearly one of the most vulnerable branches of literature. It was created for public presentation in theatres, after all, for which reason authors had to be particularly careful in their wording. On the other hand, plays provided both authors and directors with opportunities to conceal messages between the lines. For this reason, theatre became exceedingly popular in Estonia by the final decades of the Soviet era. The ridicule and mocking of the Soviet regime were especially enjoyed.

The subjugation of Estonian intellectual and spiritual life to the ideological requirements of the occupying regime was launched at the time of pre-war Stalinism (1940-1941). Its aim was to rear Soviet-minded people who would help to justify, fortify and enhance the Soviet regime. The systematic control of the activities of creative persons and the working out of dictates and regulations were nevertheless not yet completed during the first year of Soviet rule. Many outstanding cultural figures remained silent 
or earned a living by translating texts. At that time, Hugo Raudsepp wrote the non-political novel Viimne eurooplane [The Last European], which is noteworthy to this day, while his plays from the period of independent Estonian statehood were not staged in theatres.

Starting with the German occupation (1941-1944), the point of departure for Hugo Raudsepp was writing between the lines in his comedies in order to get both readers and theatregoers to think and to give them strength of soul. In 1943, he wrote the comedy Vaheliku vapustused [Interspatial Jolts], which has later been styled as a masterpiece. He concealed numerous signs between the lines of this play referring to the fate of a small people, in other words Estonia, between its great neighbouring powers the Soviet Union and Germany. Performances of this play were soon banned. Performances in theatres of all other plays by Hugo Raudsepp were similarly banned, with one exception.

During post-war Stalinism in 1944-51, the sovietisation of Estonian cultural life resumed. Hugo Raudsepp did not initially write on topical Soviet themes, rather he sought subject matter from earlier times. His first play from that period entitled Rotid [Rats] (1946) was about the German occupation during the Second World War and it ridiculed the occupying Germans. Raudsepp also skilfully wove messages supporting Estonian cultural identity into the play. The play was staged in the Estonia Theatre but was soon banned.

Raudsepp's second play from that period, Tagatipu Tiisenoosen (1946), earned first prize at the state comedy competition in that same year. The action in the play was set in the period of Estonian National Awakening at the end of the $19^{\text {th }}$ century. It ridiculed Baltic Germans and the behaviour of parvenu Estonians. Similarly to his previous play, he demonstrated nationalist mentality in this comedy by way of nationalist songs. It is noteworthy that by the summer of 1947, Tagatipu Tiisenoosen had also reached expatriate Estonians and it was staged with an altered title as the only Stalinist-era play from Soviet Estonia in Canada (1952), Australia (1954) and Sweden (1956).

The thematic precepts imposed on Estonian writers and the mechanism for ensuring that those precepts were followed became even stricter starting in 1947. Raudsepp wrote his next 7 plays on required Soviet subject matter: post-war land reform (Tillereinu peremehed [The Owners of Tillereinu], 1947), monetary reform (Noorsulane Ilmar [Ilmar the Young Farmhand], 1948), kolkhozes (Küpsuseksam [Matriculation Exam] and Lasteaed [Kindergarten], 1949, Mineviku köidikuis [In the Fetters of the 
Past] (1950) and his so-called Viimane näidend [Last Play], 1950 or 1951), and the beginning of the Soviet regime in Estonia in 1940 (Pööripäevad Kikerpillis [Solstices in Kikerpill], 1949). Hugo Raudsepp skilfully wove words of wisdom for Estonians on surviving under foreign rule through the mouths of his characters, or discreetly laughed about Soviet reality in a way that the censors did not grasp.

Post-war cultural policy culminated with the $8^{\text {th }}$ Plenum of the Estonian Communist (Bolshevist) Party (EC(B)P) Central Committee on 21-26 March 1950, where among other things, the EC(B)P Central Committee Bureau was accused of allowing the exaltation of the superiority of Western European science and culture. Cultural figures were branded bourgeois nationalists and they faced serious ordeals. The fate of the great figure of Estonian dramatic literature was very harsh. Hugo Raudsepp was depicted as a 'fascist henchman' in 1950. He was expelled from the Estonian Writers' Union and was deprived of his personal pension. He was arrested on 11 May 1951. Opposition to the Soviet regime was stressed in the charges presented to him. His play Vaheliku vapustused, which the German occupying regime had banned, and his only play that was allowed at that time, Lipud tormis [Flags in the Storm], were named as the primary evidence supporting the charges. Hugo Raudsepp was sentenced to 10 years imprisonment in the autumn of 1951 . He hoped to the last possible moment that he would be allowed to serve his sentence in Estonia. Unfortunately, on 18 February 1952 he was sent by train from Tallinn to Narva and on 19 February on to Leningrad. From there his journey took him to Vjatka, Kirov and finally Irkutsk oblast. This great man's health was poor, and he soon died on 15 September 1952.

Very few new literary works appeared in the 1940s. The historical nadir is altogether seen in post-war book production in the era of Stalinism. Estonian theatre was similarly in a most difficult situation due to censorship, shortage of repertoire, scarcity of funding, and layoffs and sackings of theatre personnel. Nowadays the survival of theatre at the time, regardless of difficult times, is appreciated, and actors are recognised for preserving Estonian identity and uniting the people.

Hugo Raudsepp's role as a playwright in supporting intellectual and spiritual resistance to foreign authorities has to be recognised on the basis of his occupation-era comedies. Hugo Raudsepp was one of the most productive authors of his day, writing a total of 11 plays in 1943-51. According to the assessment of scholars of literature, he never once rose with these works to the leading-edge level of his previous works. It was impossible 
to create masterpieces that would become classics in that time of strict ideological precepts and the monitoring of their observance. Taking into consideration the extremely restricted creative conditions, his works were still masterpieces of their time. As Hugo Raudsepp's oeuvre demonstrates, spirit still managed to cleverly trump power regardless of censorship and official precepts. The denunciation of Stalin's personality cult in 1956 once again opened the door to the theatre for Hugo Raudsepp's best comedies from Estonia's era of independent statehood. The witticism and laughter of Hugo Raudsepp's comedies gave people renewed strength of soul.

KEYwORDS: Second World War; resistance; drama; Hugo Raudsepp

Anu Raudsepp is Associate Professor at the Institute of History and Archaeology, University of Tartu*

* Correspondence: Institute of History and Archaeology, University of Tartu, Jakobi 2, 51003, Estonia. E-mail: anu.raudsepp@ut.ee 